\title{
Penentuan Variabel yang Berpengaruh dalam Penyediaan Air Bersih dengan Konsep Corporate Social Responsibility di Kabupaten Lamongan
}

\author{
Inas Yaumi Aisharya dan Hertiari Idajati \\ Perencanaan Wilayah dan Kota, Fakultas Teknik Sipil dan Perencanaan, Institut Teknologi Sepuluh \\ Nopember (ITS) \\ e-mail: ide_archits@yahoo.com
}

\begin{abstract}
Abstrak-Kabupaten Lamongan merupakan salah satu kabupaten yang mengalami krisis air bersih yang terus meluas tiap tahunnya. Terdapat alternatif dalam penyediaan air bersih berupa skema kerjasama konsep Corporate Social Responsibility namun selama ini pelaksanaannya masih belum sesuai dengan kebutuhan. Oleh karena itu, penelitian ini bertujuan untuk menentukan variabel yang berpengaruh dalam penyediaan air bersih dengan konsep CSR. Metode analisis yang digunakan pada penelitian ini adalah content analysis. Hasil penelitian menunjukkan bahwa dari 9 variabel, terdapat 5 variabel yang berpengaruh, yaitu kebijakan tarif air bersih, jumlah dan debit sumber air bersih, kualitas air bersih, pengelola air bersih, dan pendanaan untuk air bersih. Sedangkan 4 variabel lain yang tidak berpengaruh adalah jumlah penduduk, ukuran wilayah, sarana penyediaan air bersih, dan lokasi sumber air bersih.
\end{abstract}

Kata Kunci-Air Bersih, Corporate Social Responsibility.

\section{PENDAHULUAN}

$M$ ENURUT RTRW Kabupaten Lamongan 2008-2028, kebutuhan air bersih masyarakat Kabupaten Lamongan dilayani oleh PDAM, sumur pompa, sudetan Sungai Bengawan Solo, waduk, serta mata air. Namun pengelolaan sumber air dan pendistribusiannya kepada masyarakat masih dikatakan kurang.

Sumber air bersih yang berupa waduk di Lamongan saat ini hanya tersisa tiga waduk dari 44 waduk yang masih memiliki cadangan air, yakni Waduk Prijetan, Waduk Gondang, dan Waduk Caling. Cadangan air yang ada sudah tidak bisa dikeluarkan karena akan merusak struktur waduk, walaupun dapat diambil secara manual menggunakan jerigen [1]. Sedangkan kondisi air bersih pada sumur bor yang digunakan oleh 50,42\% penduduk di Kabupaten Lamongan kondisi airnya payau sehingga tidak dapat dimanfaatkan dengan baik [2].

Dalam rangka menjamin pemenuhan hak rakyat atas air minum dan akses terhadap air minum, dikeluarkanlah Peraturan Pemerintah Republik Indonesia Nomor 16 Tahun 2005 Tentang Pengembangan Sistem Penyediaan Air Minum (SPAM). Program tersebut baru melayani sekitar 3\% dari keseluruhan target yang dicanangkan [3]. Sedangkan masih ada 19 desa di 10 kecamatan di Lamongan bagian selatan yang mengalami krisis air bersih [4]. Hal ini juga diperkuat dari Laporan Teknis Infrastruktur Kabupaten Lamongan Tahun 2011-2012 yang menyatakan pelayanan air bersih pada tahun 2010 mencapai $23,2 \%$ dan melayani penurunan lingkup pelayanan menjadi 22,83\% dari keseluruhan Kabupaten Lamongan.

Kabupaten Lamongan perlu melakukan investasi kerjasama antara pemerintah daerah dan pihak swasta untuk memenuhi kebutuhan air baku di Kabupaten Lamongan [5]. Dalam rangka memberikan pelayanan air bersih, pemerintah Kabupaten Lamongan mengeluarkan surat edaran yang berisi tentang undangan kerjasama penyediaan air bersih dengan skema Public Private Partnership [6].

Alternatif kerjasama pemerintah dan swasta yang lain di antaranya adalah Neo-liberal/bisnis, Corporate Accountability, sosial ekonomi, dan Corporate Social Responsibility [7]. Corporate Social Responsibility adalah jenis kerjasma yang sedang menjadi trend di Indonesia beberapa tahun belakangan ini [8].

Penyediaan air bersih dengan konsep CSR di Kabupaten Lamongan telah dilaksanakan beberapa kali. Namun menurut penuturan Kepala Bidang Air Bersih dan Sanitasi Dinas PU Cipta Karya Kabupaten Lamongan, penyediaan air bersih dengan konsep CSR mengalami beberapa permasalahan, antara lain kurang tepatnya bentuk bantuan yang diberikan, kurang tepatnya lokasi yang dipilih, bantuan yang diberikan dinilai kurang berkelanjutan, serta permasalahan komunikasi dengan pemerintah daerah setempat. Sedangkan perusahaan swasta biasanya telah memiliki kriteria lokasi dan bentuk bantuannya tertentu yang bergantung pada kondisi perusahaan itu sendiri.

Berdasarkan pembahasan di atas, Kabupaten Lamongan memiliki permasalahan dalam penyediaan air bersih. Kondisi tersebut seharusnya dapat diselesaikan dengan program Corporate Social Responsibility oleh perusahaan swasta yang beroperasi di Kabupaten Lamongan. Oleh karena itu, diperlukan adanya penelitian mengenai penentuan variabel yang mempengaruhi penyediaan air bersih dengan konsep CSR di Kabupaten Lamongan 


\section{METODE PENELITIAN}

Penelitian ini menggunakan metode content analysis untuk menentukan variabel yang berpengaruh dalam penyediaan air bersih dengan program CSR. Content Analysis merujuk pada metode analisis yang integratif dan bertujuan untuk menemukan, mengidentifikasi, mengolah, dan menganalisis dokumen untuk memahami makna, signifikansi, dan relevansinya [9].

Data-data yang dibutuhkan dalam penelitian ini adalah pendapat para stakeholders dalam penyediaan air bersih yang dilakukan dengan wawancara mendalam. Stakeholders yang dimaksud pada penelitian ini terbagi dua, instansi pemerintah dan perusahaan penyedia program CSR air bersih. Instansi pemerintah yang terkait dalam penelitian ini di antaranya adalah Badan Perencanaan dan Pembangunan Daerah Kabupaten Lamongan, Dinas PU Cipta Karya, serta Perusahaan Daerah Air Minum Kabupaten Lamongan. Sedangkan perusahaan penyedia CSR air bersih dalam penelitian ini merupakan perusahaan yang telah melakukan bantuan CSR air bersih di Lamongan seperti RS.Muhammadiyah Lamongan dan Sunan Group atau yang berpotensi memberikan bantuan CSR air bersih di Lamongan seperti PT.Petrokimia Gresik. Survei sekunder juga dilakukan untuk mengetahui gambaran umum di wilayah penelitian. Wilayah penelitian dapat dilihat pada gambar di bawah ini:

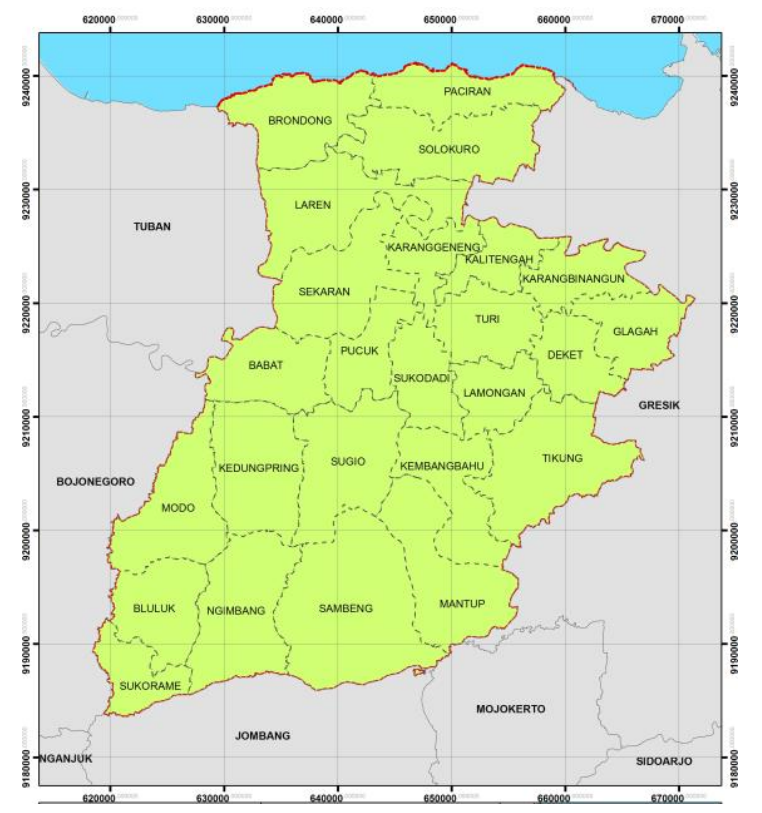

Gambar 1. Peta Wilayah Penelitian.

Dasaran dalam melakukan wawancara, diperlukan variabel penelitian. Dalam penelitian ini, variabelnya antara lain seperti yang tertera pada Tabel 1 .

Tabel 1.

Variabel Penelitian

\begin{tabular}{lll}
\hline \multicolumn{2}{c}{ Variabel Penelitian } \\
\hline \hline & Indikator & Variabel \\
& Kebutuhan Air & Jumlah Penduduk \\
Bersih & Ukuran Wilayah \\
Air Bersih & & Kebijakan tarif air bersih \\
& & Sarana Penyediaan Air \\
\hline
\end{tabular}

\begin{tabular}{ll}
\hline \hline Sumber Air Bersih & Lokasi sumber air \\
& Jumlah dan debit sumber air \\
& Kualitas Sumber Air \\
\hline \hline
\end{tabular}

Sumber: Hasil Analisis, 2017

\section{HASIL DAN PEMBAHASAN}

\section{A. Hasil Pengodean dan Penyederhanaan Data}

Pengodean dilakukan untuk menemukan kode yang mengindikasikan pengaruh variabel pada penyediaan air bersih dengan konsp CSR. Hasil pengodean didasarkan oleh transkrip wawancara 6 stakeholders yang sebelumnya telah dilakukan wawancara mendalam. Berikut contoh penemuan kode dalam transkrip wawancara:

\begin{tabular}{|c|c|}
\hline \multicolumn{2}{|l|}{ G2 : Oh Bekasi. Kalau di Lamongan saya ndak tanya. } \\
\hline Kalau...kalau...kalau karakteristik di lamongan itu kita & A6.1 \\
\hline mengandalkan air permukaan. Air permukaan kan, seperti yang & \\
\hline diketahui seperti air tampung air hujan, air Bengawan solo... kita & A6.2 \\
\hline $\begin{array}{l}\text { masih tergantung itu. Karena untuk..untuk air bawah tanahnya } \\
\text { susah karena kita rawa. Daerah... daerah Lamongan itu kita ikut }\end{array}$ & A6.3 \\
\hline
\end{tabular}

Gambar 2. Kutipan Temuan Kode pad Stakeholder 2 (G2) Transkrip 2.

Berdasarkan kutipan di atas, diketahui bahwa terdapat unit Analisis yang diutarakan oleh stakeholder 2 (G2), yang mengindikasikan makna bahwa variabel debit air (A6) merupakan hal yang berpengaruh terhadap penyediaan air bersih dikarenakan sumber air yang selama ini digunakan memiliki jumlah air yang belum mencukupi. Indikasi tersebut menyimpulkan bahwa stakeholder 2 menganggap variabel ini berpenaruh. Proses pengodean menitikberatkan terhadap makna unit Analisis berlaku pada stakeholder lainnya. Selain makna unit Analisis yang mengindikasikan pengaruh, unit Analisis yang jumlahnya berulang dengan makna yang sama mendukung penyimpulan indikasi dan signifikansi suatu pengaruh variabel terhadap penyediaan air bersih di Kabupaten Lamongan. Hasil pengodean tersebut disederhanakan dalam bentuk tabel di bawah ini.

Tabel 2.

Frekuensi Konfirmasi Stakeholders tiap Variabel

\begin{tabular}{|c|c|c|}
\hline \multirow[b]{2}{*}{ Variabel } & \multicolumn{2}{|c|}{ Jumlah Stakeholders } \\
\hline & $\begin{array}{l}\text { Mengonfirmasi } \\
\text { Berpengaruh }\end{array}$ & $\begin{array}{l}\text { Mengonfirmasi } \\
\text { tidak Berpengaruh }\end{array}$ \\
\hline Jumlah Penduduk & 2 & 4 \\
\hline Ukuran Wilayah & 2 & 4 \\
\hline $\begin{array}{l}\text { Kebijakan tarif air } \\
\text { bersih }\end{array}$ & 5 & 1 \\
\hline $\begin{array}{l}\text { Sarana Penyediaan } \\
\text { Air }\end{array}$ & 3 & 3 \\
\hline Lokasi sumber air & 4 & 2 \\
\hline $\begin{array}{l}\text { Jumlah dan debit } \\
\text { sumber air }\end{array}$ & 4 & 2 \\
\hline Kualitas Sumber Air & 4 & 2 \\
\hline Pengelola Air Bersih & 5 & 1 \\
\hline Pendanaan & 4 & 2 \\
\hline
\end{tabular}

Sumber: Hasil Analisis, 2017

Tabel 3.

Frekuensi Unit Analisis tiap Variabel dengan Maksud yang Sama pada Seluruh Stakeholders 


\begin{tabular}{lll}
\hline \hline & \multicolumn{2}{c}{ Jumlah Frekuensi } \\
\cline { 2 - 3 } \multicolumn{1}{c}{ Variabel } & $\begin{array}{l}\text { Frekuensi } \\
\text { Indikasi } \\
\text { Pengaruh }\end{array}$ & $\begin{array}{l}\text { Frekuensi } \\
\text { Indikasi Tidak } \\
\text { Pengaruh }\end{array}$ \\
\hline Jumlah Penduduk & 6 & 4 \\
Ukuran Wilayah & 2 & 4 \\
Kebijakan tarif air bersih & 14 & 1 \\
Sarana Penyediaan Air & 8 & 3 \\
Lokasi sumber air & 13 & 2 \\
Jumlah dan debit sumber air & 12 & 3 \\
Kualitas Sumber Air & 8 & 1 \\
\hline Pengelola Air Bersih & 21 & 1 \\
\hline Pendanaan & 10 & 2 \\
\hline \hline
\end{tabular}

Sumber: Hasil Analisis, 2017

Berdasarkan hasil wawancara, terdapat dua variabel tambahan yang disebutkan oleh sebagian besar stakeholder dan paling sering disebutkan pada transkrip wawancara, di antaranya adalah variabel pengelola air bersih dan variabel pendanaan.

Berdasarkan kedua tabel tersebut, terlihat bahwa terjadi kecenderungan indikasi pengaruh suatu variabel berdasarkan stakeholders dan frekuensi unit analisisnya. Hasil tersebut menunjukkan bahwa variabel kebijakan tarif air bersih dan pengelola air bersih merupakan variabel yang dikonfirmasi oleh sebagian besar stakeholders, dan juga menjadi variabel yang dominan karena paling sering diulang dalam keseluruhan transkip wawancara, di mana variabel kebijakan tarif diulang 13 kali dan variabel pengelola air bersih diulang sebanyak 21 kali.

\section{B. Hasil Pemahaman Data}

Pada tahapan pemahaman data, hasil pengodean dan penyederhanaan data yang telah dilakukan di atas kembali dieksplorasi dengan melihat kembali keterkaitan penyediaan air bersih terhadap program Corporate Social Responsibility dengan kembali mengulik apa yang dibicarakan oleh perusahaan sebagai pihak yang mengadakan program CSR.

Tabel 4.

Frekuensi Frekuensi Konfirmasi serta frekuensi unit Analisis oleh perusahaan

\begin{tabular}{lll}
\hline \hline Variabel & $\begin{array}{l}\text { Perusahaan } \\
\text { Mengonfirmasi } \\
\text { Berpengaruh }\end{array}$ & $\begin{array}{l}\text { Frekuensi } \\
\text { Unit } \\
\text { Analisis }\end{array}$ \\
\hline Jumlah Penduduk & 1 & 1 \\
Ukuran Wilayah & 0 & 0 \\
Kebijakan tarif air bersih & 2 & 3 \\
Sarana Penyediaan Air & 0 & 0 \\
Lokasi sumber air & 1 & 2 \\
Jumlah dan debit sumber & 1 & 1 \\
air & 1 & 2 \\
Kualitas Sumber Air & 1 & 2 \\
Pengelola Air Bersih & 2 & 1 \\
\hline Pendanaan & 1 & \\
\hline \hline Sumber: Hasil Analisis, 2017 &
\end{tabular}

Berdasarkan rekapitulasi transkrip wawancara oleh pihak perusahaan, diketahui bahwa variabel yang paling berpengaruh dalam penyediaan air bersih dengan konsep CSR adalah pengelola air bersih dan tarif air bersih. Sehingga dapat diambil kseimpulan bahwa dari 9 variabel yang muncul pada wawancara, hanya terdapat 5 variabel yang berpengaruh terhadap penyediaan air bersih dengan konsep CSR, yaitu kebijakan tarif air bersih, jumlah dan debit sumber air, kualitas sumber air, pengelola air bersih, dan pendanaan air bersih.

Terdapat variabel yang apabila dilihat berdasarkan frekuensi muncul pada transkrip wawancara merupakan variabel berpengaruh, namun apabila dilihat keterkaitannya dengan program CSR bukan merupakan variabel yang berpengaruh, seperti variabel lokasi sumber air bersih (A5). Seperi yang dapat dilihat pada gambar di bawah ini:

kekurangan air bersih. Pada waktu musim kemarau, kita ngambilnya air itu bisa sampai sepuluh-lima belas kilo, gitu. Nah sekarang setelah adanya CSR ini, mulai bulan..e..dua ribu enam belas kalau nggak salah itu ulan april ya, kita sudah bisa, sudah siap

Gambar 3. Kutipan Temuan Kode pada Stakeholder 5 (P2) Transkrip 5.

Pada cuplikan transkrip tersebut oleh stakeholder 5 (P2), mengatakan bahwa selama ini air yang diambil lokasinya berada jauh dari permukiman, sehingga dapat disimpulkan bahwa lokasi sumber air tidak berpengaruh terhadap penyediaan air bersih dengan konsep CSR.

\section{Penarasian (Abstraksi Hasil)}

Kabupaten Lamongan selama ini mengandalkan sumber air dari Sungai Bengawan Solo dan waduk-waduk yang tersebar di Lamongan. Sungai Bengawan Solo yang letaknya relatif di bagian utara Kabupaten Lamongan, ternyata memiliki debit air yang fluktuatif bergantung pada musim. Selain itu, ketika musim kemarau tiba, Sungai Bengawan Solo rawan terintrusi air laut yang menyebabkan tingginya kadar garam pada air sehingga tidak sesuai dengan standar kualitas air bersih. Begitu pula dengan waduk yang memiliki debit air bergantung pada musim. Sedangkan mata air memiliki jarak yang cukup jauh dari permukiman sehingga masyarakat harus berjalan berkilokilo meter untuk mendapatkan air bersih. Alternatif lain adalah mengadakan sumur bor. Namun sumur bor juga rawan mendapatkan air yang bercampur dengan air laut pada Lamongan bagian utara, dan kapur pada Lamongan bagian selatan.

Di sisi lain, Lamongan sebenarnya memiliki potensi lain karena terdapat SPAM regional yang bekerja sama dengan Kabupaten Mojokerto dalam penyediaan air bersih. Sumbernya didapat dari Sungai Brantas. Namun hal ini terkendala akibat sistem perpipaan yang belum memadai.

Sistem perpipaan dinilai lebih bersifat kontinu dibanding hanya mengambil air di sumur atau mata air. Namun kondisinya saat ini pipa yang ada masih belum tercukupi kapasitasnya, padahal kebutuhan air bersih cukup tinggi. Sedangkan kondisinya saat ini banyak pipa yang usianya sudah cukup tua sehingga dinilai kurang baik dalam mendistribusikan air bersih karena menyebabkan tingkat kebocoran yang cukup tinggi, yakni antara 30 hingga 40 persen. 
Air bersih selama ini disediakan oleh PDAM yang statusnya sakit. Jangkauan PDAM pun masih di area pusat perkotaan Kabupaten Lamongan. Karena hal tersebut, maka muncullah penyedia air yang lain seperti HIPPAM yang mendominasi, dan Perusahaan Jasa Tirta namun hanya melayani sangat sedikit di Kabupaten Lamongan.

Kendala tersebut diakibatkan oleh kurangnya pendanaan untuk penyediaan air bersih. Air bersih dianggarkan pada APBD Kabupaten Lamongan. Sedangkan untuk SPAM regional menggunakan dana APBD Provinsi Jawa Timur, dan APBN untuk wilayah Pantura. Pihak penyelenggara air bersih tidak dapat menaikkan tarifnya karena tarif air bersih sudah ditetapkan dan memiliki fungsi sosial. Padahal masyarakat sangat membutuhkan air bersih yang sebenarnya tidak akan keberatan untuk membayar berapapun tarif yang dipasang.

\section{KESIMPULAN}

Berdasarkan hasil Analisis dan pembahasan yang telah dilakukan pada penelitian ini, maka dapat disimpulkan bahwa:

Beberapa hal yang penting diperhatikan oleh penulis:

1) Variabel pengelola air bersih dan kebijakan tarif air bersih merupakan yang paling berpengaruh dalam penyediaan air bersih dengan konsep CSR melihat dari jumlah konfirmasi pengaruh oleh stakeholder dan iterasi unit analisis, di mana 5 dari 6 stakeholder mengindikasikan variabel tersebut berengaruh dengan pengulangan unit analisis dengan maksud yang sama, di manauntuk pengelola air bersih mengalami pengulangan sebanyak 21 kali dan 14 kali untuk kebijakan air bersih.

2) 4 dari 9 variabel, yaitu jumlah penduduk, ukuran wilayah, sarana penyediaan air, serta lokasi sumber air bersih bukan merupakan variabel yang berpengaruh terhadap penyediaan air bersih dengan konsep CSR karena frekuensi penyebutan oleh pihak perusahaan sebagai penyelenggara program CSR air bersih tidak signifikan

3) Penyediaan air bersih dengan konsep CSR dipengaruhi oleh 5 variabel, di antaranya adalah kebijakan tarif air bersih, jumlah dan debit sumber air, kualitas sumber air, pengelola air bersih, serta pendanaan air bersih.

4) Penelitian ini hanya melihat persepsi stakeholders terpilih dan teori yang relevan sehingga untuk penelitian selanjutnya dibutuhkan kajian empiris berbasis observasi untuk meningkatkan validitas.

\section{DAFTAR PUSTAKA}

[1] N. Qomar, "Pos Kota. Retrieved from Pos Kota News," 2015. [Online]. Available: http://poskotanews.com/2015/10/21/sebanyak41-waduk-di-lamongan-kering/.

[2] Rencana Tata Ruang Wilayah Kabupaten Lamongan Tahun 20082028. .

[3] H. Mashuri, "Surya. Retrieved from Surabaya Tribunnews," Surabaya Tribunnews, 2015. [Online]. Available: http://surabaya.tribunnews.com/2015/10/30/kekeringan-dan-krisisair-bersih-meluas-di-81-desa-di-lamongan.

[4] E. Sudjarwo, "Retrieved from DetikNews," Detik News, 2015. [Online]. Available: http://news.detik.com/berita-jawatimur/3039458/kekeringan-di-lamongan-meluas-10-kecamatankrisis-air-bersih.

[5] E. Noviyanti, Penyediaan Air Bersih Pada Kawasan Rawan Air Bersih Di Pesisir Utara Lamongan. Tata Loka, 2014.

[6] Bappeda, Expression Of Interest Lamongan Public Private Partnership (Ppp) Water Supply Project. Lamongan, 2013.

[7] Reed, Ananya Mukherjee and Darryl, "Corporate Social Responsibility,Public Private Partnership and Human Development: Towards a New Agenda (and Beyond), Copenhagen Business Scholl, Copenhagen," 2006.

[8] B. B. Tanudjaja, "Perkembangan Corporate Social Responsibility di Indonesia," Nimana, pp. 92-98, 2006.

[9] B. Bungin, Metodologi Penelitian Kualitatif. Jakarta: PT. Rajagrafindo Persada, 2001. 